\title{
DRIVERS OF INVESTOR MOTIVATIONS FOR IMPACT INVESTMENTS: THE CASE OF MICROFINANCE
}

\author{
Julia Meyer*, Annette Krauss*, Kremena Bachmann**1
}

Preliminary version, 15 April 2019

\begin{abstract}
Recent empirical research shows that both financial and value-related considerations prevail for an individual's decision to invest in companies or products deemed sustainable or socially responsible. This paper investigates how different investor motivations vary across forms of sustainable investment strategies, in particular between broad sustainable investments and targeted impact investments. We use a unique dataset of retail investors engaged in a development oriented microfinance investment vehicle to analyze how different motives affect the demand for distinct sustainable investments. Our results show that different motives trigger different types of sustainable investments. While decisions to engage in general sustainable investments are mainly linked to return and risk expectations, the investment decision for the impact investment vehicle is connected more strongly to value attributes. In line with previous findings on general sustainable investments, we find that the decision to invest is driven more by value-related criteria while the amount invested is driven by financial motivations. Our analysis furthermore shows that distrust in the financial markets is a major driver for the share invested in general sustainable investments, but not in impact investments.
\end{abstract}

JEL Classification: G10, G11, G21, G23

Keywords: impact investing, sustainable investing, investor motivations, behavioral finance, microfinance

\footnotetext{
* University of Zurich, Department of Banking and Finance, Center for Sustainable Finance and Private Wealth, Plattenstrasse 32, 8032 Zürich, Switzerland

** University of Zurich, Department of Banking and Finance, Plattenstrasse 32, 8032 Zürich, Switzerland Corresponding author: Annette.krauss@bf.uzh.ch
} 


\section{INTRODUCTION}

The volume of sustainable investments, shortly SI, has grown considerably during the last few years in developed economies' financial markets, according to reports of industry associations active in promoting SI, such as Eurosif, US SIF, the Forum Nachhaltige Geldanlagen (FNG), and Swiss Sustainable Finance (SSF). SI focus not only on financial returns but also on environmental, social and governance (shortly ESG) factors. These factors could affect risks, contribute to returns, or constitute stand-alone investment objectives. A variety of distinct sustainable investing approaches or strategies are subsumed in practice under this umbrella definition (see Eurosif 2016). Impact investment as a subgroup of SI is defined as investment with the intention to generate social and environmental impact alongside--below, at, or above market level---financial returns (Höchstädter and Scheck 2015). This paper analyzes the factors that affect the individual demand for different types of assets that are deemed sustainable or impact investments. A body of theoretical and empirical literature on motivations of investors to engage in sustainable investments has emerged. Yet, extant research does not differentiate between different types of SI investments. As the range of SI is broad, and the concepts applied by individuals to define what is "sustainable" or "socially responsible" vary between individuals (Berry and Junkus 2013), it is likely that decisions to prioritize non-financial achievements of investments and easily forgo financial returns depends on the type of investment strategy or product chosen.

Extant research based on market data observes investment flows in and out of SI, measured in assets labeled or rated sustainable, and their sensitivity to past performance (for instance, Hartzmark and Sussman 2019; Renneboog, Ter Horst, and Zhang 2011; Benson and Humphrey 2008; Bollen 2007). They show that investments in SI are less sensitive to past performance, even past losses, than other investments tend to be. This market-based approach, however, does not allow a differentiation between different types of investors, their motivations, and decision biases. 
A more granular examination of individual investor decisions requires investigation at the micro level. The rapidly growing body of empirical literature on the motivations of SI investors typically focuses on distinct sub-samples of the population, using either experimental settings (Gutsche and Ziegler 2016; Barreda-Tarrazona, Matallín-Sáez, and Balaguer-Franch 2011; Glac 2009; Webley, Lewis, and Mackenzie 2001), survey-based data (Brodback, Guenster, and Mezger 2019; Dorfleitner and Utz 2014; Berry and Junkus 2013), administrative investor portfolio data, or a combination thereof (Bauer, Ruof, and Smeets 2019; Riedl and Smeets 2017; Borgers and Pownall 2014). Experimental research designs testing investment decisions in a laboratory setting aim to eliminate social desirability biases of survey-based research, while they may also encounter limitations in terms of generalizability, framing biases and social desirability bias caused by the experimental setting itself (Levitt and List 2007).

Our paper contributes to this body of empirical literature as we examine how individual differences in motivations and expectations with respect to risks, returns, loss tolerances and non-financial motivations vary with the demand for various SI types, and how those factors shape the realized investment decisions. We consider two types of SI investments: investments in broader SI strategies and a specific type of social-oriented impact investing vehicle.

Our analysis is based on a unique dataset of individual retail investors based in Switzerland. The data is hand-collected through a survey among investors and potential investors in a clearly impact-oriented investment vehicle in microfinance (more recently labelled financial inclusion). While our survey approach cannot fully exclude selection bias and common method bias, it allows us to evaluate individual characteristics and link them to individual investment decisions. The individual characteristics include measures on the relative return and risk expectations, risk tolerance, motivations, as well as socio-economic characteristics. The individual investment decisions are evaluated with respect to two different SI strat- 
egies, i.e. investments in the specific microfinance vehicle or other impact investments and investments in broader publicly traded SI vehicles (stocks, bonds, and funds).

The remainder of this paper is organized as follows. Section 2 develops our hypotheses based on a review of the literature. In Section 3, we describe our empirical approach, data, and variables, and develop the statistical models and estimation strategy. We discuss summary statistics and results in Section 4 . Section 5 contains a discussion of robustness tests and limitations, and section 6 concludes.

\section{BACKGROUND AND HYPOTHESES}

\subsection{SUSTAINABLE INVESTMENT STRATEGIES}

The definition of SI captures a set of different investment strategies. They range from the simple avoidance ("exclusion") of investments in companies that pursue specific activities or products deemed undesirable by the investor, to seeking to finance activities or purposes especially desired or promoted by ethical or societal norms, to the active engagement with the invested company management, boards, and voting bodies in order to achieve such purposes. The most prevalent SI strategies are commonly defined as listed in Table 1, which also shows that an increase in the sustainability focus tends to come with a reduction of the investment universe (Hummel, Laun, and Krauss 2019). ${ }^{2}$ Another important distinction is that a broader sustainability focus tends to include a wide range of factors related to environmental, social and governance (ESG) issues as defined in practice (see, for instance, CFA Institute 2015) into a SI strategy, whereas core strategies rather focus on selected topics within the broad ESG range.

With few exceptions (Døskeland and Pedersen 2016; Scheck, Hochstädter, and Busch 2016), the empirical research on investors behavior toward SI usually subsumes investor's sustainable investment in a general category such as "SRI fund",

2 Interestingly, the distinction used in earlier years between "broad" and "core" SI strategies (Eurosif 2012) has recently been avoided in practice and led to stronger variation in SI strategy definitions and amounts reported (FNG 2018; SSF 2018). 
or "ESG investment strategy". Yet, sustainable investment strategies imply a broad range of very different non-financial and financial return perspectives. In particular we expect that the willingness to pay for sustainable performance differ between impact investments and other forms of SI investments.

\subsection{Motivations to INVEST to ACHIEVE SOCIAL AND ENVIRONMENTAL PERFORMANCE}

A descriptive stream of the literature develops investor typologies that either follow practice-oriented categorizations of specific market participants such as institutional investors, qualified individual investors (high net worth individuals), retail individual investors, or pension fund beneficiaries. Or they categorize investor motivations into few archetypical categories, acknowledging that both financial and non-financial objectives are frequently associated with SI (Utz, Wimmer, and Steuer 2015; Lewis and Mackenzie 2000). (Glac 2009) subsumes motivations for SI under just two possible mental models, i.e., "expressive" and "financial". (Bénabou and Tirole 2010) and Ariely, Bracha, and Meier (2009) use a categorization into "intrinsic" (value-motivated), "extrinsic" (reward-oriented), and image-driven" (perception-oriented) motivations. Chatterji, Levine, and Toffel (2009) distinguish four types of investors according to their motivations. Besides "non-financial value-driven" (deontological) investors, "consequentialist" investors seeking specific non-financial results, and "expressive" investors who consider SI as a means to express their personal identity and convey a specific "image" of themselves, they include investors seeking specific financial results related to a sustainable investment, such as portfolio diversification effects, which can be described as classical mean-variance investors. The inclusion of the latter is in line with the empirical findings reported by Derwall, Koedijk, and Ter Horst (2011).

The theoretical foundations for such classifications are laid in behavioral economics. Behavioral portfolio theory integrates an investor's goal how to use or consume the expected returns from investments into the investment decision, and postulates that investments will be chosen according to different goals (Das et al. 
2010). Behavioral portfolio theory, thus, also allows to explicitly incorporate nonfinancial goals such as a preference for non-financial aspects, labeled "affect", for a specific asset in an investment decision (Statman, Fisher, and Anginer 2008; Statman 2004). As a consequence, investors may have utility functions based on two criteria (Ballestero et al. 2012; Barreda-Tarrazona, Matallín-Sáez, and BalaguerFranch 2011; Levitt and List 2007) or on several criteria (Utz et al. 2014), where the overall utility is generated as utility based on financial factors related to risk and return, and utility based on non-financial factors such as values or the perceived sustainability or impact of investments.

In an extension of classical modern portfolio theory, an investment decision can be expressed as the solution to the following maximization problem under uncertainty, without specifying the nature of the relationship, be it additive (Utz et al. 2014; Bollen 2007) or more complex (albeit less easy to solve analytically), between financial and non-financial goals:

$\max E[U((P(x), W(x))]$

subject to:investment universe (with or without excluding short-selling)

Where U stands for utility, P for financial return, W stands for non-financial factors creating utility, and $\mathrm{x}$ for the portfolio of assets.

The application of an exclusion strategy would leave the investor with the same maximization problem under a restricted investment universe:

$\max E[U((P(x), W(x)])$

subject to: restricted investment universe, based on exclusion criteria

This combined utility function allows to differentiate investor types according to the weight attributed to the financial and non-financial aspects. The maximization problem of a classical mean-variance investor would set $E[U(W(x)]=0$ and independent from $\mathrm{P}(\mathrm{x})$ whereas an investor seeking sustainability would experience a linear (additive weighted), convex or concave combination of $P(x)$ and $W(x)$ in her utility function. Moreover, Das et al. (2010) show under which assumptions a 
mean-variance investor's decision is equivalent to the decision of a behavioral investor, and that a behavioral approach yields slightly less efficient results if investors cannot borrow against future gains. Finally, besides modelling non-financial factors in multiple-attribute utility functions, they can be modeled in referencedependent utility, in which loss aversion enters together with other parameters for risk aversion and subjective probability weighting (Xie, Hwang, and Pantelous 2018).

Applying this modified classical normative utility theory to the most differentiated typology by Chatterji, Levine, and Toffel (2009), the first two types, deontological and consequentialist investors (which correspond to intrinsic and extrinsic motivations in the classification of Ariely, Bracha, and Meier (2009), both associate nonfinancial values respectively objectives with their investment (Statman, Fisher, and Anginer 2008; Statman 2004), for instance environmental or societal concerns. The third type, expressive investors, may invest socially out of "impure altruism" motives (Andreoni 1990), for instance enjoying the "warm glow" (Andreoni 1990) of being perceived altruistic, respond to perceived societal norms (Hong and Kacperczyk 2009; Bollen 2007), or be influenced by their identification with specific social groups (Bauer and Smeets 2015). The fourth investor type would focus on the covariance of SI with other asset classes; yet, empirical studies rather found that a covariation neglect is predominant among behavioral investors (see the discussion in Duxbury 2015).

Building on Chatterji, Levine, and Toffel (2009), we expect that any investor observed will reveal a different set of motivations to invest in SI. In line with Nilsson (2008), we further expect these motivations not to be mutually exclusive, in other words, that an individual is not motivated by a single of these motivations but that for any individual investor, a mix of them, albeit to different intensities, can be found.

Depending on the type of motivation that prevails for an investor, different investment behavior can be expected for SI and for impact investments. In particular, we 
expect that investors who hold impact investments reveal what we call a valueorientation for these investments---although it cannot be excluded that such deontological and consequentialist investors might question if impact investing is as effective as charity (Scheck, Hochstädter, and Busch 2016), or that they question more generally the social impact of those impact investments that promise a combination of financial and non-financial returns. ${ }^{3}$ Alternatively, investors with a strong expressive motivation might engage in "trendy" SI or in those corresponding to their group of social identification, or they could prefer visible acts of philanthropy to impact investments due to the limited warm glow or altruistic selfimage induced by the financial return component of impact investments. It is also possible that the different motivations for an impact investment could be interdependent (Smeets, Bauer, and Gneezy 2015; Ariely, Bracha, and Meier 2009; Heyman and Ariely 2004). For instance, adding an extrinsic motivation in terms of financial award might shift the impact investor's decision from a value-driven to a monetary frame. Or impact investors could be influenced by specific social groups if these promote specific investments, thus follow extrinsic incentives and seeking social rewards rather than ESG-related impact. Incorporating the different nonfinancial motivations into the utility function underlying an investment decision leads us to the following hypothesis:

H1 The decision to invest in an impact investment is driven by valuerelated non-financial motivations, not by financial motivations.

Empirical evidence supporting our hypothesis on the need to differentiate motivational drivers includes the findings by Riedl and Smeets (2017) for a sample of Dutch retail investors. To differentiate between expressive motivations on the one hand and more intrinsic, namely value-driven and consequentialist motivations

3 For instance, microfinance investments are clearly considered impact investments (Scola, Moretto, and Lahaye 2018). Yet the risks of mission drift and financial considerations becoming more important than sustainability-related goals, is an often expressed critique toward microfinance investments im comparison to donations (see the overview of the discussion in D'Espallier, Hudon, and Szafarz 2013). 
on the other hand, they introduce a series of several round games in the giving game and the dictator game, and triangulate data from investor accounts, survey, and experimental results. They find that both social preferences and signaling explain socially responsible investment decisions, while investors are willing to sacrifice financial performance. Moreover, in a survey of a population of citizens in a German town, (Brodback, Guenster, and Mezger (2019) find a positive association of altruistic attitudes and willingness to invest in SI. In an early a survey among Swedish retail investors, Nilsson (2008) identifies that a pro-social attitude and financial perceptions are connected. Apostolakis et al. (2018) differentiate the attributes of various SI strategies more broadly in an experiment that analyses Dutch pension fund beneficiaries' selection between different SI products through a choice-based conjoint analysis. They find three groups with different attitudes toward SI: One group that felt more insecure about the outcome of SI, another group preferring to invest "conventionally", i.e. without regard to ESG criteria, and a third group willing to invest sustainably, but with less direct concern ("greater psychological distance") and a resulting inconsistent behavior when it comes to real decision-making. Moreover, financial and non-financial objectives were not always fully separated. Apostolakis' et al. (2018) approach helps reconciling earlier studies such as Rosen, Sandler, and Shani (1991) who identify investors not willing to sacrifice financial performance for sustainability performance.

All in all, the dimension of the value fraction within investors' perceived utility and its interaction with expectations toward financial factors and their volatility remains open to empirical investigation.

\subsection{MENTAL ACCOUNTS AND DISPOSITION EFFECT}

Riedl and Smeets (2017) find that for the investors in their sample of Dutch retail investors, social motives are important for the decision to invest in a sustainable fund, while the percentage invested is in turn driven by financial motives. They also find that those investors who expect SI funds to underperform conventional funds are less likely to invest sustainably. These findings hint that investors have 
distinct return expectations for SI and for conventional investments and may also have different risk thresholds or loss tolerances for different types of investments. The latter aspect is formalized in the behavioral portfolio theory of Thaler (1980), Shefrin and Statman (2000) and Das et al. (2010), according to which investors compartmentalize their portfolios into several "mental accounts" or sub-groups with different ultimate consumption goals and subsequent risk-return expectations associated to each sub-group. Risk-return expectations per mental account are formalized through a combination of thresholds under which an investment should not fall, subjective probabilities of reaching such thresholds, and expected returns. Following Webley, Lewis, and Mackenzie (2001) and MacKenzie and Lewis (1999), we apply mental accounting to the range of SI strategies and related products.

Mental accounting allows us to differentiate SI, firstly, according to their consumption quality in terms of financial returns first (conventional investments), social / environmental returns first (philanthropy, below-market impact investing, other "core" strategies), or a combination of both (broad SI strategies). Secondly, with respect to the notion of risk, standard behavioral portfolio theory assumes that mental accounts vary in the acceptance of risk. Following prospect theory, another fundamental underlying behavioral portfolio theory, individuals weigh losses more than gains, and loss aversion is separated from an investor's expectations toward probabilities of investment outcomes (Kahneman and Tversky 1979). Therefore, risk acceptance in behavioral portfolio theory is measured as thresholds of maximum loss (loss tolerance) that an investor is willing to bear for each mental account combined with the (perceived) likelihood of this to happen. As a consequence of the dislike of losses, investors are disposed to hold on to those investments that made losses and sell those that increased in value. Empirical studies supporting prospect theory show that expected returns matter more than expected volatility (Barberis and Huang 2001) and that individuals are avers to losses, not 
to the variance of losses (Duxbury 2015). Applying these definitions of the different SI strategies to the notion of risk, we expect that investors are more willing to bear losses and hold onto those investments aimed at putting non-financial returns at equal or more important than financial returns, i.e. impact investments, than for broad SI. In turn, for SI we expect that investors still show higher risk acceptance or loss tolerance than for conventional investments.

Thus, we expect that the share of investments into a specific SI-related mental account is driven by the combined return and risk notion with respect to that mental account, and that this combination also differs for each type of predominant SI motivation.

For SI in general, we expect that once the decision is made to invest in broad SI strategies, the portfolio weight accorded to these SI is driven by financial expectations. For impact investments, however, we expect that investors predominantly following value-oriented, and even more so, consequentialist, motives---gaining utility mainly through the achievement of concrete results of their actions---and would be motivated by impact performance to increase the exposure to the impact investment regardless the risk notion. We expect that in particular for impact investments, more than for broad SI, the decision about the relative or absolute size of the investment in such a product is driven by non-financial concerns:

H2 The share or amount invested in impact investments is driven by valuerelated motivations, not by financial considerations.

H3 The share invested in general SI is driven by a combination of valuerelated motivations and financial considerations.

Empirical evidence supporting $\mathrm{H} 2$ can be found in a single-round experimental survey among German retail investors done by Scheck, Hochstädter, and Busch (2016). Their results show that the absolute investment volume matters in an experimental decision to invest in specific impact products and their comparison to a donation. Moreover, with respect to H3, Riedl and Smeets (2017) also find that 
for broad SI funds, investors also pursue utility maximization through financial factors.

We argue that expressive investors mentally account for broad SI and for impact investing differently from value-driven and consequentialist investors. Image or signaling as a motive for SI implies that investors are driven by perceptions of their peers, and therefore indicates the desire to be liked (Ariely, Bracha, and Meier 2009). Expressive investors still gain major utility from financial performance while mainly using the sustainable investment as a communication tool to create a positive social image (Riedl and Smeets 2017). Thus, we expect that investors with a preference to use SI as a means of signaling in combination with comparably weak value motivations hold only a small share in impact investments:

H4 Expressive investors who use general SI or impact investment as a means to express their identity are not motivated to increase their share / amount invested in general SI, respectively in impact investment.

Finally, the disposition effect seems to hold according to the investment flow studies that show that ethical investors are committed to their investment and keep it even when the investment performs badly financially or ethically. Van Dooren and Galema (2018) find that this disposition effect is pronounced for retail social investors, mainly when they invest a substantial proportion of their portfolio in SI. This leads us to the following hypothesis:

H5 The longer an impact investment is held, the more important are nonfinancial motivations to hold the investment.

\subsection{DRIVERS OF RISK PERCEPTIONS: FRAMING INFORMATION, AND THE ROLE OF FINANCIAL MARKETS}

Subjective probability weighting can be influenced by the immediateness and framing of information. Empirical behavioral studies show the relevance of how information on investments is presented to and subsequently used by investors (Døskeland and Pedersen 2016; Markowitz, Cobb, and Hedley 2012). In other 
words, a critical role is played by investor's competence to assess potential (mis)information, with the lack of it leading to investment mistakes (see for instance Bachmann and Hens 2015).

In an application to sustainable investing, Glac (2009) shows that so-called decision frames that present specific information on financial and non-financial aspects of SI opportunities affect investment decisions. Paetzold, Busch, and Chesney (2015) find significant barriers to developing the appropriate decision frames for sustainable investing in the form of lack of information access, caused for instance by uninformed or differently motivated financial advisors. Also according to Borgers and Pownall (2014), investment decisions that are not consistent with rational behavior when including non-financial criteria are based on a lack of financial literacy and education. Moreover, psychological factors may add to an attitude behavior gap (Carrigan and Boulstridge 2000) so that investors may not even follow through with their stated or revealed investment motivations or intentions (see for instance Paetzold and Busch 2014). In an experiment conducted by Barreda-Tarrazona, Matallín-Sáez, and Balaguer-Franch (2011), participants invest more in a fund when they are explicitly informed about its sustainability characteristics. Still, information on financial aspects seem to matter more, according to a natural experiment explored by Døskeland and Pedersen (2016). In a similar vein, Pilaj (2017) elaborates a model to assess the individual decision of retail investors to invest in SI. He finds that low demand by retail investors is the result of a behavioral market failure and that nudging as "behaviorally informed policy-making" would be an appropriate tool to overcome these barriers.

This literature leads us to hypothesize that the different motivations for SI and impact investments depend on the differences in decision frames and screens that investors are using. For instance, financial advisors can be considered the most professional information source for retail investors but they may not be available. Or they may not be used for decisions to invest in SI or impact investments, and may be replaced by sources more related to the non-financial investment motives 
or directly to the products, including informal sources. Finally, an emerging body of literature on the role of trust in financial markets shows a link between active participation in financial markets and trust in it (Sapienza and Zingales 2012). Thus, we expect that:

H6 Non-financial information matters more for value-oriented investors.

H7 Financial advisors do not play an important role for the decision to invest in impact investments for value-oriented investors; they rely more on informal sources of information.

\section{DATA AND Research Methodology}

\subsection{DATA}

To investigate our hypotheses, we focus on retail investors who are investing on their own money. We investigate differences in investment decisions for SI in general and impact investments in particular. Xie, Hwang, and Pantelous (2018) argue that experiments alone tend to underestimate the role of loss aversion as tested in experiments, in comparison to real-life risk-taking or risk-avoiding decisions. Thus, our empirical approach uses survey data on a unique population of retail impact investors that are interested in or invested in a specific impact-investing vehicle. It also allows us to control for a variety of socio-economic characteristics as well as return expectations and loss tolerance for different asset classes.

Our analysis uses the responses received in a large-scale survey. Our surveyed population are investors and potential investors in a microfinance investment vehicle based in Switzerland, Oikocredit Deutsche Schweiz, shortly OCDS. ${ }^{4}$ The positioning and information material available to potential investors clearly frames OCDS as a socially oriented impact investment. More specifically, it places OCDS as a so-called microfinance development fund according to Goodman's (2007) popular classification of microfinance investment vehicles into commercial, quasi-

\footnotetext{
Oikocredit, founded in 1975 and headquartered in the Netherlands, is a worldwide cooperative and social investor, providing funding to service microfinance / financial inclusion service provides, fair trade organizations, cooperatives and small to medium enterprises. According to its Annual Report, in 2017, Oikocredit International reached EUR 1,153 million of assets under management and 40 million clients.
} 
commercial and development funds. While quasi-commercial and commercial funds are set up as traditional investment companies, development funds are often organized as cooperatives or non-profit entities (Goodman 2007). ${ }^{5}$ Moreover, our choice of OCDS for this study is motivated by the visibility and the high share that microfinance, also called financial inclusion, holds among impact investment in general (Scola, Moretto, and Lahaye 2018).

We conducted a standardized anonymized written survey among around 2000 investors and potential investors, i.e. those who had contacted OCDS during two years before the survey but decided against an investment, during the summer and fall of 2017. Answering to the 28 mostly closed-form survey questions was possible both online and in paper-and-pencil form and resulted in 728 answers and a response rate of over 36 percent.

The survey contained five sections concerning (i) motivations and objectives of investing, (ii) donations, (iii) investment decision making, (iv) investment in OCDS, and (v) demographic and socio-economic profiles of the respondents. ${ }^{6}$ The survey template is available upon request. The dataset was screened for univariate outliers and missing data, resulting in a final sample size of 721, and internal validity of response scales was tested.

\subsection{VARIABLES}

\section{DECISIONS FOR SUSTAINABLE INVESTMENTS - DEPENDENT VARIABLES}

We define three variables of interest describing the investment decisions in SI in general and in impact investments and use these as dependent variables in our empirical investigation. These are: (i) the decision to invest in OCDS as a measure for impact investment decision (OCDS yes/no), (ii) the amount---expressed in Swiss

\footnotetext{
5 OCDS as a cooperative clearly states on the website that investments are convenient for investors who "want to achieve positive social and ecological outcomes, and do not seek a maximization of financial profits" while financial return to the investors is capped at 2 percent. https://de.oikocredit.ch/geldanlage-privatpersonen, 09.05.18.

6 Only around 17percent of responses, i.e. 120, were made online. The large response rate from paper-and-pencil surveys filled by respondents themselves was unusual, and it required careful monitoring of data entry. Handwritten notes added outside of the answer boxes were not fully recorded in the full data table. Data entry was done by three transcribers, and the data quality was randomly cross-checked by the project manager and other transcribers. The resulting data is contained in a two-dimensional table with 721 line observations arranged for all 28 survey questions.
} 
Francs, CHF---invested in OCDS as a measure of amount in impact investment (Amount_OCDS), and (iii) the share of all types of SI in the portfolio as a measure of the share in general sustainable investment (Share_SI).

Specifically, we specify (i) OCDS yes/no as a binary variable that equals one if an investor is invested in OCDS. (ii) Amount_OCDS captures the amount of money invested with OCDS using the following 6 categories: 1 (less than CHF 1000), 2 (CHF 1000-CHF 5000), 3 (CHF 5000-CHF 10000), 4 (CHF 10000-CHF 20000), 5 (CHF 20000-CHF 50000), and 6 (more than CHF 50 000). Finally, (iii) Share_SI captures the percentage of wealth (without real estate and pension savings) invested in SI vehicles. The variable is defined on the basis of 6 categories: 1 (less than 1\%), 2 (1\% to $10 \%), 3(11 \%$ to $25 \%), 4(26 \%$ to $50 \%), 5$ (51\% to $75 \%)$ and 6 (76\% or more). Furthermore, we differentiate the share in SI according to the type of investment in impact investments versus broader SI investments.

\section{MOTIVATIONAL ATTRIBUTES}

To investigate our Hypotheses 1 o 3 with respect to motivational factors, we identify different motivational factors that drive investment decisions. The factors are identified using factor analysis with a Varimax rotation. The loadings of the underlying survey items assessing various motivational drivers are included in Table 2 .

The first factor can be described as the aspect that captures the combination of the different non-financial motivations or values found in the variety of responses: Non-Financials (NF). A second factor describes the financial drivers for an investment decision in an impact investment (OCDS) or in a general SI strategy: Financials $(F)$. We test for the internal validity of the motivational factors using Cronbach's alpha. ${ }^{7}$ As a robustness test, we further split the Financials factor into one variable capturing aspects related to general SI (Fin_SI) and one related to the impact investment in OCDS specifically (Fin_OCDS).

\footnotetext{
${ }^{7}$ Cronbach's alpha is 0.814 for the factor "Non-Financials" and 0.794 for the factor "Financials".
} 
Consequentialist investment motives are assessed with four survey questions. Finally, with the item, "because they are trendy and have return potential", we capture the expressive attitude of investors being mainly interested in SI because they expect them to be a trend in the variable Sig for signaling.

\section{RETURN AND RISK EXPECTATIONS AND LOSS TOLERANCE}

We elicit the individual perception of the risk and return potential of different asset classes, namely the range of standard conventional asset classes, SI in general, and the OCDS impact investment in particular. The perceived return respectively risk potential is elicited using a Likert scale ranging from 1 (very low) to 5 (very high). In addition, we ask participants for an explicit estimation of the average return that they expect from the different asset classes. We also ask for the maximum loss (in percentage per annum) that each respondent would be willing to bear, for each of the asset classes, which we use in the context of the average expected return to calculate a proxy of the individual loss aversion for each asset class (losstolerance).

\section{INVESTMENT EXPERIENCE AND INFORMATION SOURCES}

We use different control variables in the analysis. We use the experience of losses with different asset classes as a proxy for investment experience. Additionally, we control for individual differences in the information sources used to making financial and investment decisions (v_invinf) as well as for individual differences in the level of mistrust in financial markets.

\subsection{MODEL SPECIFICATION}

We estimate the following three linear models:

$$
\begin{aligned}
& \text { OCDS }_{i}=\alpha+\beta_{1} N F_{i}+\beta_{2} F_{i}+\beta_{3} \text { Sig }+ \text { Controls }_{i}+\varepsilon_{i} \\
& \text { Amount_OCDS }_{i}=\alpha+\beta_{1} N F_{i}+\beta_{2} F_{i}+\beta_{3} \text { Sig }_{i}+\text { Controls }_{i}+\varepsilon_{i} \\
& \text { Share_SI }_{i}=\alpha+\beta_{1} N F_{i}+\beta_{2} F_{i}+\beta_{3} \text { Sig }_{i}+\text { Controls }_{i}+\varepsilon_{i t}
\end{aligned}
$$


Model (1) is estimated using a logistic regression. Model (2) and (3) are estimated with interval regressions. In addition, ordered logit regressions are used as robustness tests.

Besides the two factors described above (Non-Financials NF, Financials F), we include four standard socio-economic variables, age, education, income, and gender (v_age, v_edu, v-income, v_gender) as controls.

\section{Results}

\subsection{CHARACTERISTICS OF INVESTORS IN THE SURVEY}

We provide descriptive statistics of the sample population in Table 3. In particular, the respondents' age distribution and educational level is quite distinct, with a vast majority of around 83 percent being 50 years or older, and almost 73 percent having a university degree or an advanced professional degree. Another noticeable characteristic of the surveyed population of retail investors interested in microfinance impact investing is that 86 percent of all respondents state that they donate more than the Swiss average of CHF 600 per year for philanthropy. Around 14 percent of the respondents have not invested in OCDS after soliciting investment information from OCDS. This constitutes a control group compared to the 532 who are invested. Given the differences in response rates of both sub-groups, we test for observable heterogeneity in the sub-samples but find that the groups are rather homogeneous with the exception of the higher share of female respondents among those not invested, and a slightly different educational structure.

The absolute risk and return expectations for different asset classes are summarized in Table 4 and in Figure 1. Respondents perceive the impact investment in OCDS and other SI investments very similar, and they perceive them both similar to bonds from both a risk and a return perspective. In other words, respondents seem not to differentiate between the different types of SI and impact investments, in contrast to our hypotheses. Moreover, respondents' stated loss tolerance for OCDS investments is similar to the one to derivatives, but lower than for stocks (Figure 2). 
Finally, we compare a specific subset of respondents, namely those who are only invested in OCDS as their sole impact or SI investment but who do not hold any other SI product, in Table 5. Interestingly, OCDS-only investors hold significantly more other basic investments (namely, bank account and pension solution) than slightly more sophisticated investment products (namely, listed funds, bonds and stocks, and real estate) and significantly less complex investments (namely, direct participations, commodities, hedge funds, and structured products). On the other hand, OCDS investors who also hold other SI products have significantly more other non-listed SI investments that can be considered impact investments (investments in developing countries, direct participations, social enterprises in Switzerland, foundations).

\subsection{INVESTOR MOTIVATIONS}

We report our main findings with respect to our three models and Hypotheses 1 to 3 in Table 6.

First, our findings are in line with Hypothesis 1, as for impact investors, values are more important than financial considerations according to row (1) and column (1) in Table 6: The decision to invest in OCDS is strongly significantly related to value considerations. Financial factors are negatively related to the decision to invest, but the significance is weak. This means that actual investors in OCDS perceive the financial return of OCDS as not important for their decision. The control variables are all not significantly related to the decision to invest in OCDS.

However, the analysis does not support Hypothesis 2 with respect to a different mental account for impact investments versus SI in general. We find that the amount invested in OCDS is not significantly related to non-financials (column 2 in Table 6). For the amount invested, financial considerations are more important as shown in the positive coefficient of 0.238 , with is strongly significant. This result indicates that while the first decision to invest in the specific impact investment 
venture seems to be driven by values, the amount invested is determined by financial considerations. This observation is in line with the results of Smeets and Riedl (2017) for SI fund investments in general.

For the share of all portfolio investments held in all types of SI (column 3 in Table 6 ), we find that non-financials (NF) matter significantly at the $5 \%$ level, while financial factors do not. Taken together, these findings only partly support our $\mathbf{H y -}$ pothesis 3 that investments in general SI are driven by financial considerations compared to impact investments.

With respect to the influence of the expressive motivational factor, we find that the variable capturing the interest to hold SI or OCDS specifically as a mean to express one's identity (row for variable Signaling), is not related to the decision to invest in OCDS. At the same time, supporting our Hypothesis 4, we find that the amount invested in OCDS and the share of the portfolio in ESG are both negatively related to the signaling variable. This result makes intuitively sense, as investors seem to gain utility through having SI in their portfolio when this fact can be communicated and therefore serve as a signal to the outside. As those investors seem not to gain additional utility by the non-final achievement of the investment, i.e. the resulting outcome or impact, the amount or share invested matters less for those types of investors. In other words, the expressive motivation is not sufficient to hold large shares or amounts, independently of the type of SI chosen.

We find no significant relation between the socio-economic control variables and the decision to engage in OCDS. The variables "amount invested in OCDS" is significantly related to the level of education and the age, and the variable "share in $\mathrm{SI}^{\prime \prime}$ is weaker but still significantly related to the level of education. Keeping in mind that our sample is located in Switzerland, which is characterized by high levels of per capita income, we find no significant effect for the income for OCDS, while we find a slightly negative relation to the share of the portfolio invested in SI in general (column 3 in Table 86). We find no significant gender differences. 
We further disentangle the non-financial component in a combination of variables measuring the consequentialist orientation of an investor, namely the aim to concretely achieve environmental or social results (see Table 1 for details), versus a general value orientation. Our survey measures the consequentialist motivation for SI in general through the item "because I can identify with the aims" and through three items for the OCDS investment, "to contribute to the aims of OCDS", "to achieve a socioecological impact with my investment", and to "support the cooperative organization of OCDS". All four items clearly put emphasis on the outcome or impact of the investment and stand in contrast to the survey items focusing on the concrete value aspects, "because I have a good feeling" and "the investment is in line with my moral compass". We therefore look at the two aspects of value orientation separately. Results displayed in Table 7 show that for the decision to invest in OCDS, the consequentialist variables clearly dominate. Nevertheless and somewhat in contrast to our Hypothesis 2 but again supporting the findings of Riedl and Smeets (2017), we do not find that consequentialist motivations are also related to the amount spent in OCDS, but that they are in line with those for general SI strategies; thus, the amount or share spent is more driven by financial considerations.

\subsection{MORE ON MENTAL ACCOUNTS}

With respect to our three models and following Riedl and Smeets (2017), we further test our Hypotheses 2 to 3 by looking at the importance of the risk and return expectations vis-à-vis OCDS and SI in general as an additional indicator for financial preferences and different mental accounts.

As shown in Table 8, the relative risk and return expectation compared to stocks (namely, the expected return of SI or OCDS minus the expected return of stocks) seems to matter, while we find no significant effect for the absolute risk and return expectations for OCDS and SI (results not shown in table). We find some moderating effects on the coefficients of the motivational factors investigated so far. The relative return expectation for OCDS respectively SI is related significantly (at the 
$5 \%$ level) to both the amount in OCDS (column 2) and the share in SI (column 3). Furthermore, once the relative return expectation of OCDS is considered, the importance of values weakens somewhat for the decision to invest in OCDS (see column 1 in Table 8) and disappears for the share in SI in general (see column 4 in Table 8).

Moreover, the decision to invest in OCDS is less strongly related to the non-financial motivational attributes included after controlling for relative return expectations. Whereas, the share in SI in general is now significantly driven by the financial factor in addition to the relative return expectations. This result thus further supports our Hypothesis 3 that investments in SI are driven by a combination of financial targets and values. Note that this result holds when measured through a survey item asking for concrete return expectations while it was not strongly supported when measured through factors derived from purely qualitatively stated motivational survey items. This result could be driven by a social desirability bias pronounced more strongly in qualitative than in quantitative survey questions.

The results with respect to relative risk and return expectations and loss tolerances (reported in Figure 2) could be explained through the notion that Swiss investors are considered to have a higher level of investment competence (Bachmann and Hens 2016), and that a higher share of households hold common stocks ${ }^{8}$ compared to some of its European neighbors. Thus, investors in the sample may have aboveaverage capabilities to assess the return potential of different asset classes, and therefore better estimate the relative potential of SI.

The fact that only the relative return expectation is influencing investors indicates that this result is mainly driven by their expectation of stock returns. As the return expectation is calculated by subtracting the return expectation toward stocks from the return expectation toward OCDS or SI in general, the positive sign of the coef-

8 Deutsche Boerse, 2016, Aktionärsquote weltweit, from website, www.boerse.de/dai/anteilaktionaere/grafik, 09.05.2018. 
ficient indicates that higher expectations toward average annual stock returns decrease the probability to engage with OCDS or SI in general. We come back to this phenomenon when discussing the role of information on and trust in financial markets more specifically.

Finally, we do not find support for Hypothesis 5 related to the length of an investment and the disposition effect, as for long-term investments in particular of more than five years in OCDS, values are not significantly related to the amount in OCDS, nor to the share in SI. We furthermore find the same results for the share of SI in the portfolio (see 
Table 9). We do find, however, that the influence of relative return expectations for OCDS matters for long-term investors but not for new investors in the OCDS impact vehicle.

\subsection{ATTITUDE AND INFORMATION ON FINANCIAL MARKETS}

With regard to potential framing drivers of perceptions of investment types, asset classes, and risk and returns, we focus on different types of information sources that survey respondents value. To test Hypothesis 6, we investigate the importance accorded to information regarding the "effect" of their investment in OCDS and of detailed financial and institutional information. A simple correlation analysis shown in Table $\mathbf{1 0}$ provides descriptive support for the hypothesis, as value-oriented investors are significantly more likely to ask for more information about the effect of the investment than financially oriented investors.

With respect to the role of financial information, we do not find descriptive evidence to support our Hypothesis 7 regarding the less important role of financial advisors compared to informal sources of information. The lack of correlation may be due to the low response rate to the information items asked, and the fact that a specific informal source, namely church-based information sources, was not asked in the survey but was mentioned in a number of responses to an open answer category.

To further investigate the role of information, we show the influence of the variable "distrust in financial markets" (measured among the motivational survey items) in Table 11. Interestingly, this variable turns out to be a main driver for larger shares of the portfolio held in SI in general. While not related to OCDS, nor to the amount invested in OCDS, the variable measuring general mistrust in financial markets significantly relates to the share in SI with a coefficient of 0.152 at the $1 \%$ level. This indicates that an investor who scales distrust in financial markets as one category higher in importance, would allocate a share of $1.5 \%$ more of his portfolio to SI in general. Finally, this result is another support to our main argument 
that the investment in an impact fund is a proactive decision for this specific venture out of value (deontologist or consequentialist) motivations, while the involvement in SI in general could be driven by a more general concern toward the role of financial markets and institutions.

\section{ROBUSTNESS CHECKS}

As an alternative measure for investment decisions so far captured through our three dependent variables OCDS_invested, share_OCDS and Share_SI, we divide the sample into "impact investors" (those invested in specific and non-listed impact investments) and "general SI investors" (those invested in listed SI products). We base this on a survey question asking for other types of SI in the portfolio (see Table 12). With respect to our Hypothesis 1, results in Table 13.

The results support our hypotheses as well, showing that the sub-sample of those classified as impact investors decides significantly based on values, while for the other part of the sample there is no significant relation with values. The coefficient of financials is even negative for the impact investor sample, meaning that impact investors do not consider financial aspects of SI as particularly relevant. For the investors engaged in public ESG, financial considerations matter significantly.

We additionally run different tests using alternative empirical regression models for the two categorical dependent variables (share_SI and amount_OCDS), such as interval regression and find that our results support the model used above (see Table 14).

Furthermore, our analysis faces limitations due to the survey methodology used. Due to confidentiality reasons, we are not able to validate survey-based data, in particular responses on invested portfolios, by triangulating with external data sources. As a result, common method biases can be excluded only as much as the survey structure and content control for such biases. Beyond these controls, three biases persist. First, the survey only reports on investors and potential investors in a particular impact investment vehicle. Second, in order to mobilize the candidates 
for participation, the vehicle, when inviting its investors and potential investors to participate in the survey, promised that for each response received, the organization would donate a small amount for an international program that contributes to protecting and supporting microfinance borrowers. Third, the response rates of two sub-groups of respondents, those invested in the vehicle and those who decided against an investment, differ significantly, which limits the significance of findings related to the last group due to possible unobserved heterogeneity. The first bias limits external validity, as we cannot extrapolate responses beyond the surveyed population. We consider the second bias as negligible given the low amount of monetary consequence of participating in the survey.

\section{DISCUSSION AND CONCLUSIONS}

In this paper, we test if findings on investor motivations to invest generally in products labeled or deemed sustainable apply equally for the specific and distinct subgroup of impact investments. As impact investments are often not publicly traded and investors have---in contrast to philanthropic donors---the possibility to withdraw their invested amounts, their investment behavior can significantly influence liquidity considerations and strategical choices of asset managers of impact investments, with the potential to affect the impact-oriented mission of the underlying investment. This underpins the importance of studying the motivation behind the involvement of investors and their specific characteristics.

Our findings show that the decision to invest in the impact investment product OCDS is significantly driven by value considerations, whereas financials seem not to play a major role. At the same time, we find that the amount allocated to the vehicle is in turn driven by financial factors. While this result is in line with existing research on more general SI products, it is surprising, as we would have expected that value-driven or even more so, consequentialist investors have an incentive to increase their investment in order to maximize non-financial outcomes. 
Our finding could be driven by the fact that investors to date may not able to sufficiently distinguish the financial and non-financial concepts behind different sustainable investment approaches. It could also be linked to the strong level of general distrust toward financial markets and information sources identified for the surveyed population sample. As a consequence, we recommend to foster further information and education of both retail investors as well as financial advisors dealing with retail clients to clarify the different concepts behind SI.

The relative difference to stocks in terms of risk and return expectations is a powerful predictor of investment choices. We furthermore find that the share of general SI in the portfolio is also considerably driven by values, but this relation completely disappears when controlling for the relative return expectations of SI visà-vis stocks. As this result is mainly driven by the fact that surveyed investors have lower return expectations for stocks, we also test for a measure of distrust in financial markets and find this variable to be strongly related to the share of SI investments in the portfolio. This result could indicate that the investment in an impact investment product is a proactive decision for this specific venture, while the involvement in SI in general could be driven by a general attitude of concern toward financial markets. Our results suggest that the decision to invest in an impact venture is strongly driven by value considerations, while the amount is more related to financials. For the share in general SI in turn, the relative return expectation and herewith the level of distrust in the financial markets is a strong driver. From a policy perspective, this outcome could imply that sustainable products are striving especially in times after financial crises when investors exhibit low levels of trust in the financial market. Yet, this result may be specific to the surveyed population and the timing of the survey and, obviously, needs additional research.

Furthermore, as the differentiation of types of motivational profiles is based on survey data, future research should include experimental designs to capture causal relationships in the attitude and decisions of individual investors toward impact investments. 


\section{REFERENCES}

Andreoni, James. 1990. "Impure Altruism and Donations to Public Goods: A Theory of WarmGlow Giving." The Economic Journal 100 (401): 464-77. https://doi.org/10.2307/2234133.

Apostolakis, George, Gert van Dijk, Frido Kraanen, and Robert J. Blomme. 2018. “Examining Socially Responsible Investment Preferences: A Discrete Choice Conjoint Experiment." Journal of Behavioral and Experimental Finance 17 (March): 83-96.

https://doi.org/10.1016/j.jbef.2018.01.001.

Ariely, Dan, Anat Bracha, and Stephan Meier. 2009. “Doing Good or Doing Well? Image Motivation and Monetary Incentives in Behaving Prosocially." American Economic Review 99 (1): 544-55. https://doi.org/10.1257/aer.99.1.544.

Bachmann, Kremena, and Thorsten Hens. 2016. "Is There Swissness in Investment Decision Behavior and Investment Competence?" Financial Markets and Portfolio Management 30 (3): 233-75. https://doi.org/10.1007/s11408-016-0274-8.

Ballestero, Enrique, Mila Bravo, Blanca Pérez-Gladish, Mar Arenas-Parra, and David Plà-Santamaria. 2012. “Socially Responsible Investment: A Multicriteria Approach to Portfolio Selection Combining Ethical and Financial Objectives." European Journal of Operational Research 216 (2): 487-94. https://doi.org/10.1016/j.ejor.2011.07.011.

Barberis, Nicholas, and Ming Huang. 2001. "Mental Accounting, Loss Aversion, and Individual Stock Returns." The Journal of Finance 56 (4): 1247-92. https://doi.org/10.1111/00221082.00367.

Barreda-Tarrazona, Iván, Juan Carlos Matallín-Sáez, and Mª Rosario Balaguer-Franch. 2011. "Measuring Investors' Socially Responsible Preferences in Mutual Funds." Journal of Business Ethics 103 (2): 305. https://doi.org/10.1007/s10551-011-0868-z.

Bauer, Rob, Tobias Ruof, and Paul Smeets. 2019. "Get Real! Individuals Prefer More Sustainable Investments." SSRN Scholarly Paper ID 3287430. Rochester, NY: Social Science Research Network. https://papers.ssrn.com/abstract=3287430.

Bauer, Rob, and Paul Smeets. 2015. "Social Identification and Investment Decisions." Journal of Economic Behavior \& Organization 117 (September): 121-34. https://doi.org/10.1016/j.jebo.2015.06.006.

Bénabou, Roland, and Jean Tirole. 2010. "Individual and Corporate Social Responsibility." Economica 77 (305): 1-19. https://doi.org/10.1111/j.1468-0335.2009.00843.x.

Benson, Karen L., and Jacquelyn E. Humphrey. 2008. "Socially Responsible Investment Funds: Investor Reaction to Current and Past Returns." Journal of Banking \& Finance 32 (9): 185059. https://doi.org/10.1016/j.jbankfin.2007.12.013.

Berry, Thomas C., and Joan C. Junkus. 2013. "Socially Responsible Investing: An Investor Perspective." Journal of Business Ethics 112 (4): 707-20. https://doi.org/10.1007/s10551-012$1567-0$.

Bollen, Nicolas P. B. 2007. "Mutual Fund Attributes and Investor Behavior.” Journal of Financial and Quantitative Analysis 42 (03): 683. https://doi.org/10.1017/S0022109000004142.

Borgers, Arian C. T., and Rachel A. J. Pownall. 2014. "Attitudes towards Socially and Environmentally Responsible Investment." Journal of Behavioral and Experimental Finance 1 (March): 27-44. https://doi.org/10.1016/j.jbef.2014.01.005.

Brodback, Daniel, Nadja Guenster, and David Mezger. 2019. "Altruism and Egoism in Investment Decisions." Review of Financial Economics 37 (1): 118-48. https://doi.org/10.1002/rfe.1053.

Carrigan, Marylyn, and Emma Boulstridge. 2000. "Do Consumers Really Care about Corporate Responsibility? Highlighting the Attitude-Behaviour Gap." Journal of Communication Management 4 (4): 355-68. https://doi.org/10.1108/eb023532.

CFA Institute. 2015. "Environmental, Social, and Governance Issues in Investing." CFA Institute. 2015. /en/advocacy/policy-positions/environmental-social-and-governance-issues-in-investing-a-guide-for-investment-professionals. 
Chatterji, Aaron, David Levine, and Michael Toffel. 2009. "How Well Do Social Ratings Actually Measure Corporate Social Responsibility?" Journal of Economics \& Management Strategy Volume 18 (Number 1): 125-169.

Das, Sanjiv, Harry Markowitz, Jonathan Scheid, and Meir Statman. 2010. "Portfolio Optimization with Mental Accounts." Journal of Financial and Quantitative Analysis 45 (2): 311-34.

Derwall, Jeroen, Kees Koedijk, and Jenke Ter Horst. 2011. "A Tale of Values-Driven and ProfitSeeking Social Investors." Journal of Banking \& Finance 35 (8): 2137-47. https://doi.org/10.1016/j.jbankfin.2011.01.009.

D’Espallier, Bert, Marek Hudon, and Ariane Szafarz. 2013. “Unsubsidized Microfinance Institutions." Economics Letters 120 (2): 174-76. https://doi.org/10.1016/j.econlet.2013.04.021.

Dooren, Bono van, and Rients Galema. 2018. "Socially Responsible Investors and the Disposition Effect." Journal of Behavioral and Experimental Finance 17 (March): 42-52. https://doi.org/10.1016/j.jbef.2017.12.006.

Dorfleitner, Gregor, and Sebastian Utz. 2014. "Profiling German-Speaking Socially Responsible Investors." Qualitative Research in Financial Markets 6 (2): 118-56. https://doi.org/10.1108/QRFM-07-2012-0024.

Døskeland, Trond, and Lars Jacob Tynes Pedersen. 2016. "Investing with Brain or Heart? A Field Experiment on Responsible Investment." Management Science 62 (6): 1632-44. https://doi.org/10.1287/mnsc.2015.2208.

Duxbury, Darren. 2015. “Behavioral Finance: Insights from Experiments I: Theory and Financial Markets." Review of Behavioural Finance 7 (1): 78-96. https://doi.org/10.1108/RBF-03-20150011.

Eurosif. 2012. "European SRI Study 2012."

Eurosif. 2016. "European SRI Study 2016."

FNG. 2018. “Marktbericht Nachhaltige Geldanlagen 2018 Deutschland, Österreich Und Die Schweiz." Forum Nachhaltige Geldanlagen.

GIIN. 2018. “Impact Investing." The GIIN. 2018. https://thegiin.org/impact-investing/.

Glac, Katherina. 2009. “Understanding Socially Responsible Investing: The Effect of Decision Frames and Trade-off Options." Journal of Business Ethics 87 (1): 41-55. https://doi.org/10.1007/s10551-008-9800-6.

Goodman, Patrick. 2007. "Microfinance Investment Funds: Objectives, Players, Potential." In Microfinance Investment Funds: Leveraging Private Capital for Economic Growth and Poverty Reduction, edited by J. D. Von Pischke and Ingrid Matthäus-Meier. Berlin ; New York: Springer.

Gutsche, Gunnar, and Andreas Ziegler. 2016. "Are Privatve Investors Willing to Pay for Sustainable Investments? A Stated Choice Experiment." https://www.econstor.eu/bitstream/10419/155652/1/873803698.pdf.

Hartzmark, Samuel M., and Abigail B. Sussman. 2019. “Do Investors Value Sustainability? A Natural Experiment Examining Ranking and Fund Flows." SSRN Scholarly Paper ID 3016092. Rochester, NY: Social Science Research Network. https://papers.ssrn.com/abstract $=3016092$.

Heyman, James, and Dan Ariely. 2004. "Effort for Payment: A Tale of Two Markets." Psychological Science 15 (11): 787-93. https://doi.org/10.1111/j.0956-7976.2004.00757.x.

Höchstädter, Anna Katharina, and Barbara Scheck. 2015. “What's in a Name: An Analysis of Impact Investing Understandings by Academics and Practitioners." Journal of Business Ethics 132 (2): 449-75. https://doi.org/10.1007/s10551-014-2327-0.

Hong, Harrison, and Marcin Kacperczyk. 2009. "The Price of Sin: The Effects of Social Norms on Markets." Journal of Financial Economics 93 (1): 15-36. https://doi.org/10.1016/j.jfineco.2008.09.001.

Hummel, Katrin, Ute Laun, and Annette Krauss. 2019. “Integration Ökologischer Und Sozialer Aspekte in Das Kerngeschäft Europäischer Banken." Jahrbuch Für Finanz- Und Rechnungswesen. 
Kahneman, Daniel, and Amos Tversky. 1979. "Prospect Theory: An Analysis of Decision under Risk." Econometrica 47 (2): 263. https://doi.org/10.2307/1914185.

Krauss, Annette, Philipp Krüger, and Julia Meyer. 2016. "Sustainable Finance in Switzerland: Where Do We Stand?" Swiss Finance Institute White Paper.

Levitt, Steven D., and John A. List. 2007. "What Do Laboratory Experiments Measuring Social Preferences Reveal About the Real World?" Journal of Economic Perspectives 21 (2): 153-74. https://doi.org/10.1257/jep.21.2.153.

Lewis, Alan, and Craig Mackenzie. 2000. "Morals, Money, Ethical Investing and Economic Psychology." Human Relations 53 (2): 179-91. https://doi.org/10.1177/a010699.

MacKenzie, Craig, and Alan Lewis. 1999. "Morals and Markets: The Case of Ethical Investing." Business Ethics Quarterly 9 (3): 439-52. https://doi.org/10.2307/3857511.

Markowitz, Linda, Denise Cobb, and Mark Hedley. 2012. “Framing Ambiguity: Insider/Outsiders and the Successful Legitimation Project of the Socially Responsible Mutual Fund Industry." Organization 19 (1): 3-23. https://doi.org/10.1177/1350508411398055.

Nilsson, Jonas. 2008. "Investment with a Conscience: Examining the Impact of Pro-Social Attitudes and Perceived Financial Performance on Socially Responsible Investment Behavior." Journal of Business Ethics 83 (2): 307-25. https://doi.org/10.1007/s10551-007-9621-z.

Paetzold, Falko, and Timo Busch. 2014. "Unleashing the Powerful Few: Sustainable Investing Behaviour of Wealthy Private Investors." Organization \& Environment 27 (4): 347-67. https://doi.org/10.1177/1086026614555991.

Paetzold, Falko, Timo Busch, and Marc Chesney. 2015. "More than Money: Exploring the Role of Investment Advisors for Sustainable Investing." Annals in Social Responsibility 1 (1): 195223. https://doi.org/10.1108/ASR-12-2014-0002.

Pilaj, Herwig. 2017. "The Choice Architecture of Sustainable and Responsible Investment: Nudging Investors Toward Ethical Decision-Making." Journal of Business Ethics 140 (4): 743-53. https://doi.org/10.1007/s10551-015-2877-9.

Renneboog, Luc, Jenke Ter Horst, and Chendi Zhang. 2011. “Is Ethical Money Financially Smart? Nonfinancial Attributes and Money Flows of Socially Responsible Investment Funds." Journal of Financial Intermediation 20 (4): 562-88. https://doi.org/10.1016/j.jfi.2010.12.003.

Riedl, Arno, and Paul Smeets. 2017. “Why Do Investors Hold Socially Responsible Mutual Funds?: Why Do Investors Hold Socially Responsible Mutual Funds?" The Journal of Finance 72 (6): 2505-50. https://doi.org/10.1111/jofi.12547.

Rosen, Barry N., Dennis M. Sandler, and David Shani. 1991. "Social Issues and Socially Responsible Investment Behavior: A Preliminary Empirical Investigation." The Journal of Consumer Affairs 25 (2): 221.

Sapienza, Paola, and Luigi Zingales. 2012. "A Trust Crisis." International Review of Finance 12 (2): 123-31. https://doi.org/10.1111/j.1468-2443.2012.01152.x.

Scheck, Barbara, Anna Katharina Hochstädter, and Timo Busch. 2016. "Making Money at the Expense of the Poor? An Investigation of Individuals' Preferences to Impact Invest versus Donate," no. 2: 23.

Scola, Barbara, Louise Moretto, and Estelle Lahaye. 2018. "Navigating the Next Wave of Blended Finance for Financial Inclusion."

Shefrin, Hersh, and Meir Statman. 2000. "Behavioral Portfolio Theory." The Journal of Financial and Quantitative Analysis 35 (2): 127. https://doi.org/10.2307/2676187.

Smeets, Paul, Rob Bauer, and Uri Gneezy. 2015. "Giving Behavior of Millionaires." Proceedings of the National Academy of Sciences 112 (34): 10641-44. https://doi.org/10.1073/pnas.1507949112.

SSF. 2018. “Swiss Sustainable Investment Market Study 2018." Swiss Sustainable Finance.

Statman, Meir. 2004. "What Do Investors Want," Santa Clara University Leavey School of Business, August.

Statman, Meir, Kenneth L. Fisher, and Deniz Anginer. 2008. "Affect in a Behavioral Asset-Pricing Model.” Financial Analysts Journal 64 (2): 20-29. https://doi.org/10.2469/faj.v64.n2.8. 
Thaler, Richard. 1980. "Toward a Positive Theory of Consumer Choice." Journal of Economic Behavior \& Organization 1 (1): 39-60. https://doi.org/10.1016/0167-2681(80)90051-7.

Utz, Sebastian, Maximilian Wimmer, Markus Hirschberger, and Ralph E. Steuer. 2014. “Tri-Criterion Inverse Portfolio Optimization with Application to Socially Responsible Mutual Funds." European Journal of Operational Research, 60 years following Harry Markowitz's contribution to portfolio theory and operations research, 234 (2): 491-98. https://doi.org/10.1016/j.ejor.2013.07.024.

Utz, Sebastian, Maximilian Wimmer, and Ralph E. Steuer. 2015. “Tri-Criterion Modeling for Constructing More-Sustainable Mutual Funds." European Journal of Operational Research 246 (1): 331-38. https://doi.org/10.1016/j.ejor.2015.04.035.

Webley, Paul, Alan Lewis, and Craig Mackenzie. 2001. "Commitment among Ethical Investors: An Experimental Approach." Journal of Economic Psychology 22 (1): 27-42. https://doi.org/10.1016/S0167-4870(00)00035-0.

Xie, Yuxin, Soosung Hwang, and Athanasios A. Pantelous. 2018. "Loss Aversion around the World: Empirical Evidence from Pension Funds." Journal of Banking \& Finance 88 (March): 52-62. https://doi.org/10.1016/j.jbankfin.2017.11.007. 


\section{FIGURES AND TABLES}

Table 1 Sustainable Investment Strategies

\begin{tabular}{l|l} 
Strategies & Description \\
\hline Negative / exclusionary screening & $\begin{array}{c}\text { Avoidance of specific assets due to considerations of } \\
\text { - moral values (e.g., tobacco or gambling) } \\
\text { standards and norms (e.g., human rights) } \\
\text { ethical convictions (e.g., animal testing) } \\
\text { or legal requirements (e.g., controversial armaments } \\
\text { such as cluster bombs or land mines, excluded in order } \\
\text { to comply with international conventions). }\end{array}$ \\
\hline Best-in-class/positive screening & $\begin{array}{l}\text { Investing predominantly in assets with high ESG performance, } \\
\text { different screening considerations, criteria and methods }\end{array}$ \\
\hline ESG integration & $\begin{array}{l}\text { Systematic and explicit inclusion of ESG risks and opportunities } \\
\text { in investment analysis }\end{array}$ \\
\hline Thematic investments & $\begin{array}{l}\text { Investing that is based on sustainability themes such as clean tech- } \\
\text { nologies, energy-efficient real estate, or sustainable forestry. }\end{array}$ \\
\hline Impact investing & $\begin{array}{l}\text { Investment with the intention to generate social and environmental } \\
\text { impact alongside financial return }\end{array}$ \\
\hline Active ownership & $\begin{array}{l}\text { "The practice of entering into a dialogue with companies on ESG } \\
\text { issues and exercising both ownership rights and voice to effect } \\
\text { change" }\end{array}$
\end{tabular}

Sources: Krauss, Krüger, and Meyer (2016); CFA Institute (2015); GIIN (2018).

Table 2 Motivational Factor Variables: Factor Loadings with Varimax Rotation

\section{Survey question Interested in Si / OCDS because...}

\begin{tabular}{lll}
\hline Feel good & $\mathbf{0 . 4 5 2 3}$ & 0.2800 \\
Identify with aims & $\mathbf{0 . 7 6 8 3}$ & -0.0464 \\
Contribute to goals of OCDS & $\mathbf{0 . 8 0 6 3}$ & -0.0577 \\
Achieve E/S impact with the investment & $\mathbf{0 . 8 5 2 9}$ & -0.0357 \\
Support cooperative OCDS & $\mathbf{0 . 6 2 3 1}$ & -0.0361 \\
In line with my values & $\mathbf{0 . 8 1 5 6}$ & 0.0398 \\
Pay off financially in the long term & -0.1247 & $\mathbf{0 . 7 3 8 9}$ \\
Value retention & 0.0390 & $\mathbf{0 . 7 7 5 7}$ \\
Low risk & -0.0200 & $\mathbf{0 . 7 9 2 5}$ \\
Diversification & 0.0115 & $\mathbf{0 . 5 7 3 6}$ \\
Pay off financially in the long term & 0.0273 & $\mathbf{0 . 6 8 2 1}$ \\
Safe in the long term & -0.0473 & $\mathbf{0 . 6 6 4 2}$ \\
\hline
\end{tabular}

Notes: This table summarizes the construction of the motivational factor variables, based on two Likert-scale survey questions capturing dimensions of investor's motivation to invest in SI in general and in OCDS specifically. The table reports the factor loadings of the individual items for the factors generated, NF and F. 
Table 3 Descriptive Statistics of the Sample Population (N=721)

\begin{tabular}{|c|c|c|c|c|c|}
\hline Variable Name & & $\begin{array}{l}\text { Val- } \\
\text { ues }\end{array}$ & Total respondents & Mean & Std.Dev. \\
\hline \multirow[t]{3}{*}{ Gender } & Female & 1 & $47.4 \%$ & & \\
\hline & Male & 2 & $48.3 \%$ & 1.504348 & .5003438 \\
\hline & $\mathrm{n} / \mathrm{a}$ & . & $4.3 \%$ & & \\
\hline \multirow[t]{5}{*}{ Age } & Below 30 & 1 & $0.8 \%$ & & \\
\hline & $30-49$ & 2 & $14.0 \%$ & & \\
\hline & $50-69$ & 3 & $44.2 \%$ & 3.237624 & 0.7200873 \\
\hline & 70 and more & 4 & $39.0 \%$ & & \\
\hline & $\mathrm{n} / \mathrm{a}$ & . & $1.9 \%$ & & \\
\hline \multirow[t]{5}{*}{ Education } & No graduation & 1 & $0.0 \%$ & & \\
\hline & Compulsory School & 2 & $1.4 \%$ & & \\
\hline & Secondary level & 3 & $23.2 \%$ & 3.733238 & .4737624 \\
\hline & Tertiary level & 4 & $72.7 \%$ & & \\
\hline & $\mathrm{n} / \mathrm{a}$ & . & $2.8 \%$ & & \\
\hline \multirow[t]{4}{*}{ Children } & No & 1 & $31.1 \%$ & & \\
\hline & $1-2$ & 2 & $39.5 \%$ & 1.961756 & .771815 \\
\hline & 3 and more & 3 & $27.3 \%$ & & \\
\hline & $\mathrm{n} / \mathrm{a}$ & . & $2.1 \%$ & & \\
\hline \multirow[t]{3}{*}{ Marital status } & Single & 1 & $31.8 \%$ & & \\
\hline & In partnership & 2 & $65.6 \%$ & 1.672857 & .4695054 \\
\hline & $\mathrm{n} / \mathrm{a}$ & . & $2.1 \%$ & & \\
\hline \multirow[t]{6}{*}{ Income } & Below CHF 30'000 & 1 & $4.0 \%$ & & \\
\hline & CHF 30'000 - 80'000 & 2 & $37.8 \%$ & & \\
\hline & CHF 80'001 - 120'000 & 3 & $36.1 \%$ & 2.681481 & .8229989 \\
\hline & CHF 120'001 - 500'000 & 4 & $16.5 \%$ & & \\
\hline & More than CHF 500'000 & 5 & $0.2 \%$ & & \\
\hline & $\mathrm{n} / \mathrm{a}$ & . & $6.4 \%$ & & \\
\hline \multirow[t]{2}{*}{ OCDS investment } & No & 0 & $15.1 \%$ & .8585298 & .3487478 \\
\hline & Yes & 1 & $84.9 \%$ & & \\
\hline \multirow[t]{5}{*}{ Change OCDS inv. } & Increased & 1 & $30.4 \%$ & & \\
\hline & Kept equal & 2 & $41.5 \%$ & & \\
\hline & Reduced & 3 & $1.9 \%$ & 1.998423 & 1.006298 \\
\hline & I do not invest & 4 & $14.1 \%$ & & \\
\hline & $\mathrm{n} / \mathrm{a}$ & . & $12.1 \%$ & & \\
\hline \multirow[t]{5}{*}{ Donations } & No & 0 & $0.7 \%$ & & \\
\hline & Below CHF 200 p.a. & 1 & $3.1 \%$ & & \\
\hline & CHF 200 - CHF 600 p.a. & 2 & $10.1 \%$ & 2.8159 & .5037551 \\
\hline & Above CHF 600 p.a. & 3 & $85.6 \%$ & & \\
\hline & $\mathrm{n} / \mathrm{a}$ & . & $0.6 \%$ & & \\
\hline
\end{tabular}


Table 4

Descriptive Statistics of the Investment and Factor Variables

\begin{tabular}{l|l|l|l|l|l} 
Variable & Obs, & Mean & Std. Dev. & Min & Max \\
\hline OCDS invested & 721 & .8585298 & .3487478 & 0 & 1 \\
\hline Share_SI & 615 & 2.650407 & 1.254203 & 1 & 6 \\
\hline Amount_OCDS & 651 & 3.817204 & 1.45139 & 1 & 6 \\
\hline Non-Financials (NF) & 576 & $-5.23 \mathrm{e}-11$ & 1 & -7.068162 & .7656695 \\
\hline Financials F & 576 & $1.00 \mathrm{e}-09$ & 1 & -2.171399 & 2.966894 \\
\hline Financials_OCDS & 576 & $1.00 \mathrm{e}-09$ & 1 & -2.171399 & 2.966894 \\
\hline Financials_SI & 576 & $-9.38 \mathrm{e}-11$ & 1 & -2.510105 & 3.268473 \\
\hline Relative Risk Expectation SI & 436 & 1.172018 & 1.241151 & -4 & 5 \\
\hline Relative Risk Expectation OCDS & 576 & 1.53125 & 1.22541 & -3 & 4 \\
\hline Relative Return Expectation SI & 294 & 2.226531 & 2.109015 & -3 & 20 \\
\hline Relative Return Expectation OCDS & 405 & 2.073086 & 2.010001 & -7 & 18
\end{tabular}

Notes: This table summarizes the dependent variables, the factor variables, and the variables related to relative risk and return expectations of the different mental accounts, SI in general and OCDS investments. Share_SI measures the share of all SI including impact investments such as OCDS, in the total portfolio investments of respondents in the following six categories: 1: below 1\%, 2: $1 \%$ to $10 \%, 3: 11 \%$ to $25 \%, 4: 51-$ to $75 \%$, and 6 : above $75 \%$.

Table 5 OCDS Investors: Other Types of Investments

(1) (2)

VARIABLES

OCDS invested (yes/no)
Only OCDS invested

(yes/no)

Basic_Investments

More_sophisticated_Investments

Complex_Investments

Listed_SI_Investments

$-0.092$

$(0.228)$

$0.668 * * *$

$(0.239)$

$1.606 * * *$

$-1.727 * * *$

$(0.145)$

(0.410)

Observations

721

721

Robust standard errors in parentheses

$$
* * * \mathrm{p}<0.01, * * \mathrm{p}<0.05, * \mathrm{p}<0.1
$$

Notes: This table reports estimated coefficients of a logit regression with the dependent variable OCDS invested, an indicator variable which takes the value 1 if a person is invested in OCDS, and 0 else. Independent variables in specification (1) are measured based on other types of sustainable investments (question 6 in survey template provided in the appendix), respectively based on answers to the question on other types of conventional investments (question 5 in the survey) in specification (2). 
Figure 1 Box Plots: Absolute Return and Risk Expecations for Different Asset Classes
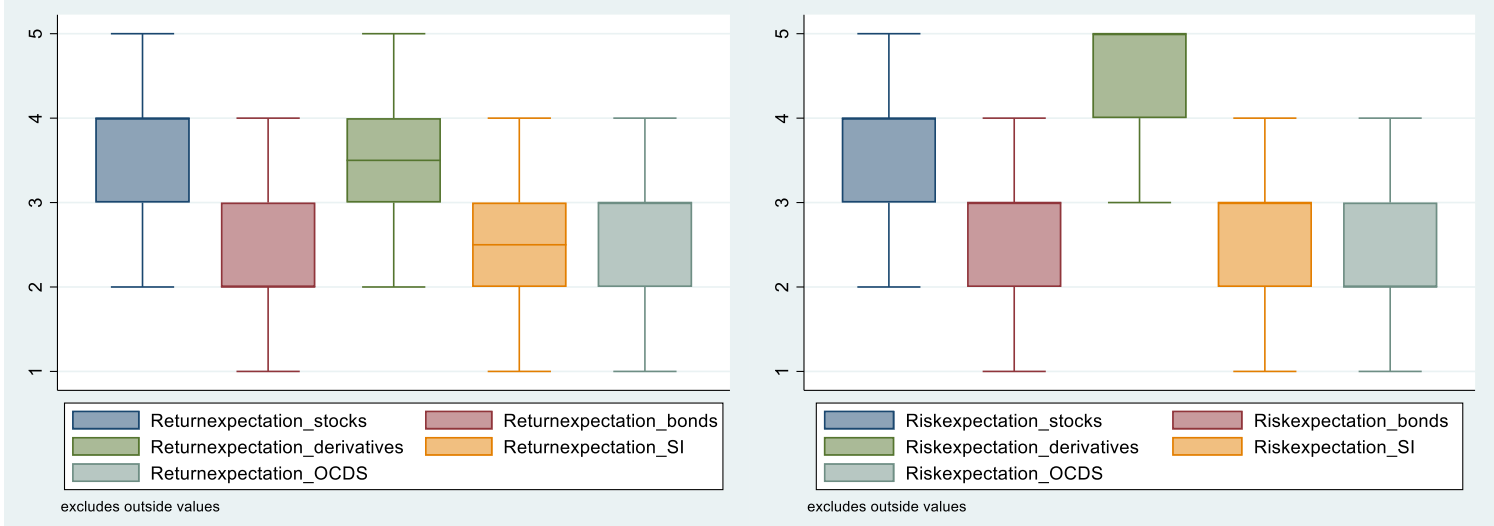

Notes: These plots describe the heterogeneity and the average level of responses to two questions on the return and risk expectation for the different types of investments and asset classes: 1: very low; 3: average; 5: very high.

\section{Figure 2 Box Plots: Loss Tolerance for Different Asset Classes}

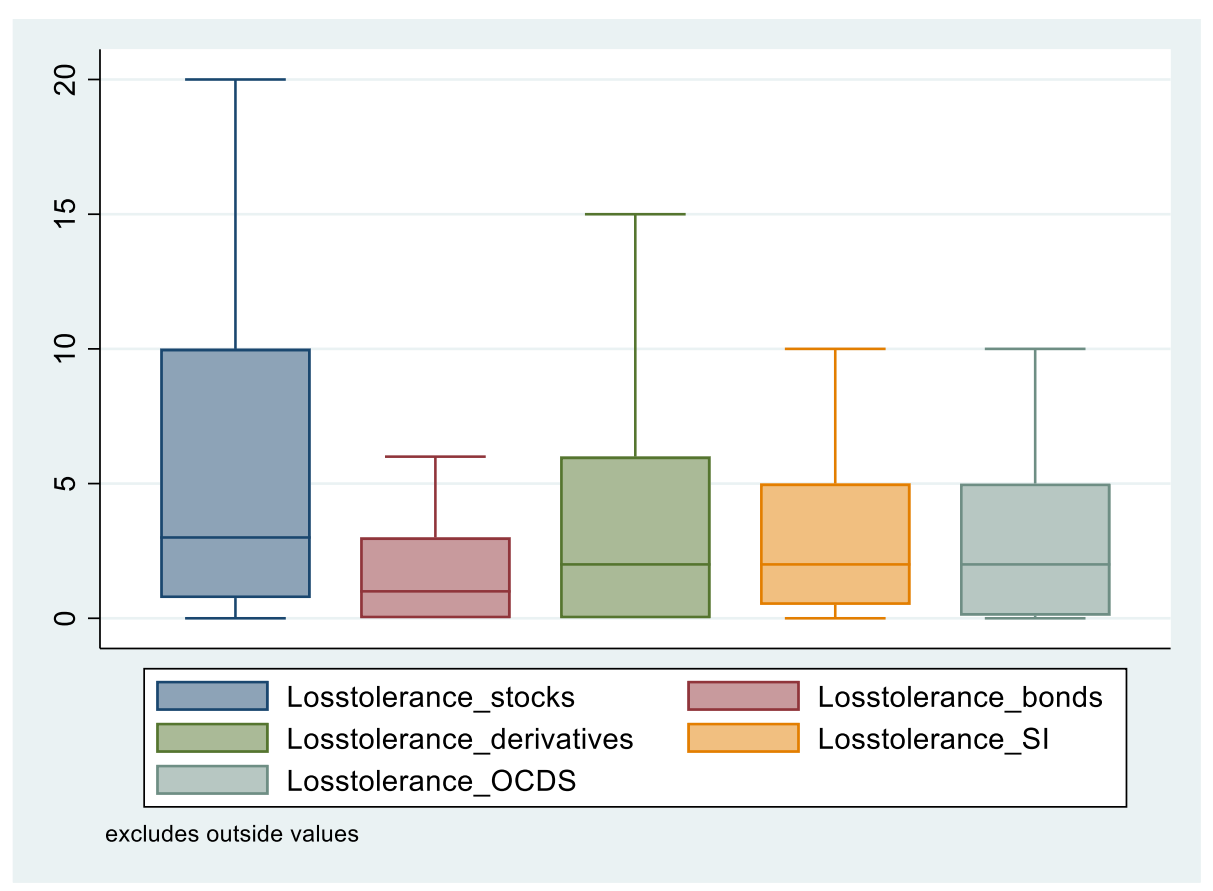

Notes: These plots describe the heterogeneity and the average level of responses to a question on the loss tolerance (in percentage) that respondents have for the different types of investments and asset classes: What is the average yearly loss that you would be willing to accept for the following assets. 
Table 6

Investment Decisions Based on Motivational Aspects

\begin{tabular}{|c|c|c|c|}
\hline VARIABLES & $\begin{array}{c}(1) \\
\text { OCDSinvested }\end{array}$ & $\begin{array}{c}(2) \\
\text { Amount_- } \\
\text { OCDS }\end{array}$ & $\begin{array}{c}\text { (4) } \\
\text { Share_SI }\end{array}$ \\
\hline Non_Financials & $\begin{array}{c}0.332 * * * \\
(0.103)\end{array}$ & $\begin{array}{c}0.038 \\
(0.083)\end{array}$ & $\begin{array}{c}0.164 * * \\
(0.075)\end{array}$ \\
\hline Financials & $\begin{array}{c}-0.234 * \\
(0.132)\end{array}$ & $\begin{array}{c}0.238 * * * \\
(0.075)\end{array}$ & $\begin{array}{c}0.056 \\
(0.066)\end{array}$ \\
\hline Signaling & 0.125 & $-0.164 * *$ & $-0.145^{* *}$ \\
\hline Age & $\begin{array}{c}(0.140) \\
-0.223 \\
(0.184)\end{array}$ & $\begin{array}{c}(0.082) \\
0.364 * * * \\
(0.103)\end{array}$ & $\begin{array}{c}(0.072) \\
-0.004 \\
(0.089)\end{array}$ \\
\hline Education & $\begin{array}{c}0.264 \\
(0.242)\end{array}$ & $\begin{array}{c}0.422 * * * \\
(0.153)\end{array}$ & $\begin{array}{l}0.261^{*} \\
(0.143)\end{array}$ \\
\hline Income & $\begin{array}{l}-0.198 \\
(0.151)\end{array}$ & $\begin{array}{c}0.115 \\
(0.100)\end{array}$ & $\begin{array}{l}-0.156 * \\
(0.088)\end{array}$ \\
\hline Gender & $\begin{array}{c}0.327 \\
(0.269)\end{array}$ & $\begin{array}{l}-0.217 \\
(0.153)\end{array}$ & $\begin{array}{c}0.088 \\
(0.138)\end{array}$ \\
\hline Constant & $\begin{array}{c}1.354 \\
(1.135)\end{array}$ & $\begin{array}{c}0.909 \\
(0.761)\end{array}$ & $\begin{array}{c}1.729 * * * \\
(0.659)\end{array}$ \\
\hline Observations & 526 & 486 & 468 \\
\hline
\end{tabular}

Notes: This table reports estimates of Equations (1-3), using an Interval regression for Amount_OCDS and Share_SI as dependent variables, and a Logit regression with the binary dependent variable OCDSinvested, which takes the value 1 if a person is invested in OCDS, and 0 else. Independent variables include the three motivational variables, namely non-financials, financials, signaling, and four control variables, age, education, income and gender.

Table $7 \quad$ Value Orientation versus Consequentialism

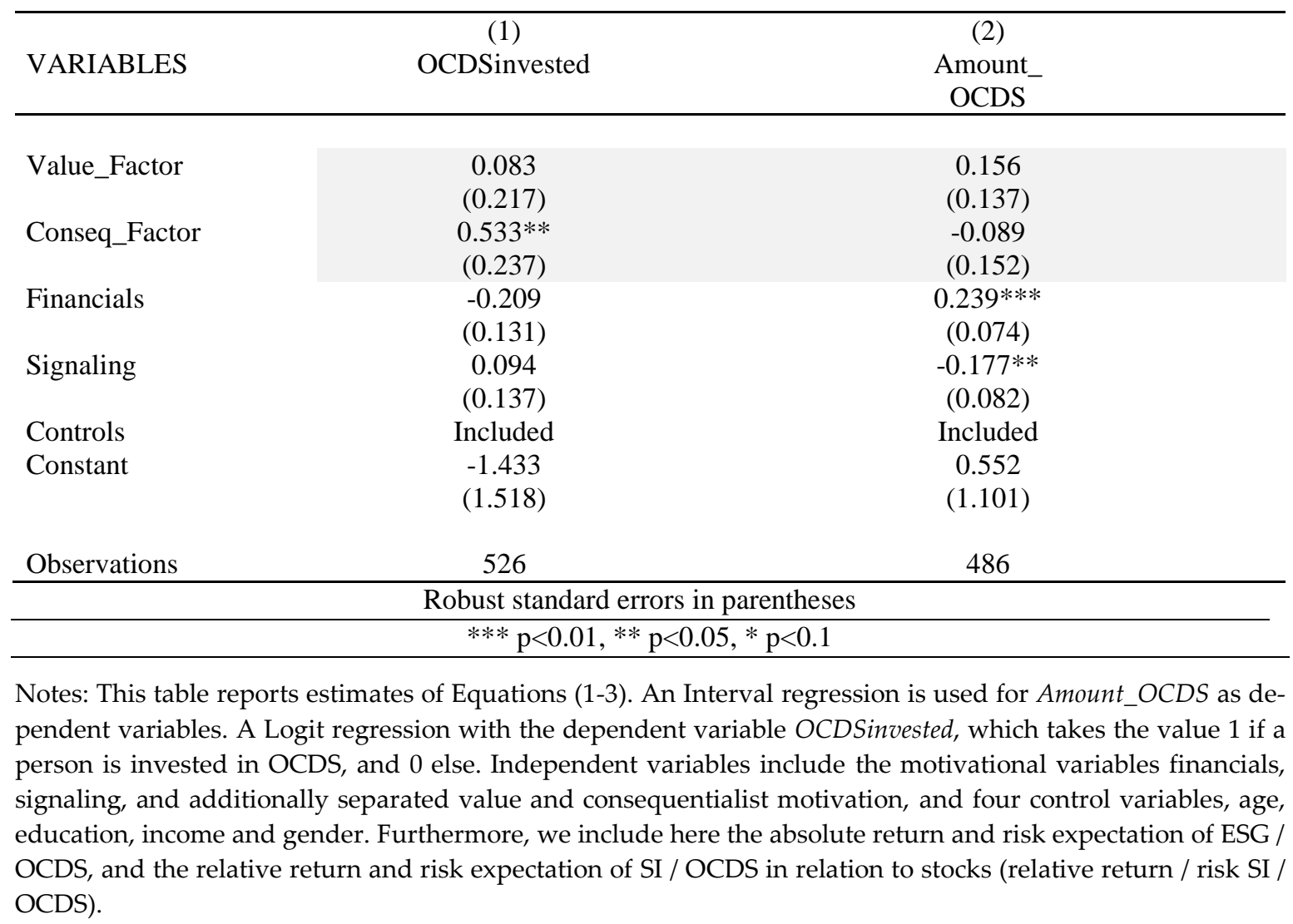


Table 8 Relative Risk and Return Expecations of SI and OCDS in Relation to Stocks

\begin{tabular}{|c|c|c|c|}
\hline VARIABLES & $\begin{array}{c}(1) \\
\text { OCDSinvested } \\
\end{array}$ & $\begin{array}{c}(2) \\
\text { Amount_OCDS }\end{array}$ & $\begin{array}{c}\text { (4) } \\
\text { Share_SI }\end{array}$ \\
\hline Non_Financials & $\begin{array}{l}0.251^{*} \\
(0.146)\end{array}$ & $\begin{array}{l}-0.016 \\
(0.102)\end{array}$ & $\begin{array}{c}0.097 \\
(0.126)\end{array}$ \\
\hline Financials & $\begin{array}{l}-0.226 \\
(0.206)\end{array}$ & $\begin{array}{c}0.382 * * * \\
(0.107)\end{array}$ & $\begin{array}{l}0.191 * \\
(0.106)\end{array}$ \\
\hline Signaling & $\begin{array}{c}0.143 \\
(0.211)\end{array}$ & $\begin{array}{c}-0.285^{* * * *} \\
(0.105)\end{array}$ & $\begin{array}{c}-0.291 * * \\
(0.124)\end{array}$ \\
\hline Relative Risk OCDS & $\begin{array}{l}-0.086 \\
(0.148)\end{array}$ & $\begin{array}{l}-0.079 \\
(0.084)\end{array}$ & \\
\hline Relative Return OCDS & $\begin{array}{c}0.065 \\
(0.075)\end{array}$ & $\begin{array}{l}0.097 * * \\
(0.041)\end{array}$ & \\
\hline Age & $\begin{array}{c}-0.510 * * \\
(0.253)\end{array}$ & $\begin{array}{c}0.441 * * * \\
(0.127)\end{array}$ & $\begin{array}{l}-0.041 \\
(0.135)\end{array}$ \\
\hline Education & $\begin{array}{c}0.009 \\
(0.376)\end{array}$ & $\begin{array}{c}0.600 * * * \\
(0.205)\end{array}$ & $\begin{array}{c}0.510 * * \\
(0.227)\end{array}$ \\
\hline Income & $\begin{array}{c}0.183 \\
(0.209)\end{array}$ & $\begin{array}{c}0.046 \\
(0.126)\end{array}$ & $\begin{array}{c}-0.274 * * \\
(0.133)\end{array}$ \\
\hline Gender & $\begin{array}{l}-0.076 \\
(0.399)\end{array}$ & $\begin{array}{c}-0.415 * * \\
(0.210)\end{array}$ & $\begin{array}{c}0.020 \\
(0.234)\end{array}$ \\
\hline Relative Risk SI & & & $\begin{array}{l}-0.088 \\
(0.090)\end{array}$ \\
\hline Relative Return SI & & & $\begin{array}{c}0.084 * * \\
(0.038)\end{array}$ \\
\hline Constant & $\begin{array}{l}3.022 * \\
(1.679)\end{array}$ & $\begin{array}{c}0.944 \\
(1.018)\end{array}$ & $\begin{array}{l}1.839 * \\
(1.071)\end{array}$ \\
\hline Observations & 311 & 293 & 201 \\
\hline
\end{tabular}

Notes: This table reports estimates of Equations (1-3), additionally controlling for the relative risk and return expectations for SI and OCDS. Interval regressions are used for Amount_OCDS and Share_SI as dependent variables. A Logit regression with the binary dependent variable OCDSinvested which takes the value 1 if a person is invested in OCDS, and 0 else. Independent variables include three motivational variables, non-financials, financials, signaling, and four control variables, age education, income and gender. Furthermore, we include here the absolute return and risk expectation of SI and OCDS, and the relative return and risk expectation of SI / OCDS in relation to stocks (relative return / risk of SI and OCDS). 
Table 9 Length of Investment: Long-term Versus Short-term Investors

\begin{tabular}{|c|c|c|c|c|}
\hline VARIABLES & $\begin{array}{l}\text { (1) } \\
\text { Long-term Inves- } \\
\text { tors: Amount_ } \\
\text { OCDS }\end{array}$ & $\begin{array}{c}(2) \\
\text { New Investors: } \\
\text { Amount__ } \\
\text { OCDS }\end{array}$ & $\begin{array}{c}\text { (3) } \\
\text { Long-term In- } \\
\text { vestors: } \\
\text { Share_SI }\end{array}$ & $\begin{array}{c}(4) \\
\text { New Investors: } \\
\text { Share_SI }\end{array}$ \\
\hline Non_Financials & $\begin{array}{c}0.015 \\
(0.109)\end{array}$ & $\begin{array}{l}-0.215 \\
(0.322)\end{array}$ & $\begin{array}{c}0.150 \\
(0.142)\end{array}$ & $\begin{array}{l}-0.119 \\
(0.426)\end{array}$ \\
\hline Financials & $\begin{array}{c}0.347 * * \\
(0.136)\end{array}$ & $\begin{array}{c}0.478 * * * \\
(0.178)\end{array}$ & $\begin{array}{c}0.284 * * \\
(0.125)\end{array}$ & $\begin{array}{l}-0.158 \\
(0.240)\end{array}$ \\
\hline Signaling & $\begin{array}{c}-0.230^{*} \\
(0.132)\end{array}$ & $\begin{array}{c}-0.399 * * \\
(0.178)\end{array}$ & $\begin{array}{c}-0.305^{* *} \\
(0.154)\end{array}$ & $\begin{array}{l}-0.366 \\
(0.249)\end{array}$ \\
\hline Relative Risk OCDS & $\begin{array}{l}-0.063 \\
(0.092)\end{array}$ & $\begin{array}{l}-0.165 \\
(0.247)\end{array}$ & & \\
\hline Relative Return OCDS & $\begin{array}{c}0.094 * * \\
(0.044)\end{array}$ & $\begin{array}{c}0.170 \\
(0.140)\end{array}$ & & \\
\hline Controls & Included & Included & Included & Included \\
\hline Constant & $\begin{array}{c}0.409 \\
(1.320)\end{array}$ & $\begin{array}{c}2.506 \\
(1.760)\end{array}$ & $\begin{array}{c}3.190 * * \\
(1.280)\end{array}$ & $\begin{array}{l}-0.475 \\
(2.107)\end{array}$ \\
\hline Observations & 226 & 67 & 152 & 49 \\
\hline
\end{tabular}

Notes: This table reports estimates of Equations (1-3), differentiating the sample into long-term (more than five years) and new OCDS investors (five years and less). Interval regressions are used for Amount_OCDS and Share_SI as dependent variables. A Logit regression with the dependent variable OCDS invested, which takes the value 1 if a person is invested in OCDS, and 0 else. Independent variables include the three factor variables non-financials, financials and signaling, and four control variables, age, education, income and gender. Furthermore, we include here the relative return and risk expectations of SI and OCDS in relation to stocks (relative return / risk SI and OCDS). 
Table 10 Investment Motivtions and Importance of Financial and Impact Information

\begin{tabular}{l|l|l}
\multicolumn{2}{l}{ Variables } & Correlation coefficient \\
\hline Value Factor & $\begin{array}{l}\text { Know more about the "Effect } \\
\text { of my investment in OCDS" }\end{array}$ & $0.1589 * * *$ \\
\hline Consequentialist Factor & $\begin{array}{l}\text { Know more about the "Effect } \\
\text { of my investment in OCDS" }\end{array}$ & $0.1100 * * *$ \\
\hline $\begin{array}{l}\text { Financials (SI and OCDS com- } \\
\text { bined) }\end{array}$ & $\begin{array}{l}\text { Know more about the "Effect } \\
\text { of my investment in OCDS }\end{array}$ & 0.0556 \\
\hline Value Factor & $\begin{array}{l}\text { Information by Family and } \\
\text { Friends }\end{array}$ & $0.0913 * * *$ \\
\hline Consequentialist & $\begin{array}{l}\text { Information by Family and } \\
\text { Friends }\end{array}$ & $0.1467 * * *$ \\
\hline $\begin{array}{l}\text { Financials (SI and OCDS com- } \\
\text { bined) }\end{array}$ & $\begin{array}{l}\text { Information by Financial Advi- } \\
\text { sor }\end{array}$ & 0.0186
\end{tabular}

Table 11 Distrust in Financial Markets

\begin{tabular}{|c|c|c|c|}
\hline VARIABLES & $\begin{array}{c}(1) \\
\text { OCDSinvested }\end{array}$ & $\begin{array}{c}(2) \\
\text { Amount } \\
\text { OCDS }\end{array}$ & $\begin{array}{c}\text { (4) } \\
\text { Share_SI }\end{array}$ \\
\hline NonFinancials & $\begin{array}{c}0.303 * * * \\
(0.102)\end{array}$ & $\begin{array}{c}0.029 \\
(0.083)\end{array}$ & $\begin{array}{l}0.133^{*} \\
(0.073)\end{array}$ \\
\hline Financials & $\begin{array}{c}-0.240^{*} \\
(0.132)\end{array}$ & $\begin{array}{c}0.237 * * * \\
(0.076)\end{array}$ & $\begin{array}{c}0.025 \\
(0.065)\end{array}$ \\
\hline Signalling & $\begin{array}{c}0.135 \\
(0.141)\end{array}$ & $\begin{array}{c}-0.170 * * \\
(0.083)\end{array}$ & $\begin{array}{c}-0.154 * * \\
(0.072)\end{array}$ \\
\hline Distrust financial markets & $\begin{array}{c}0.115 \\
(0.092)\end{array}$ & $\begin{array}{c}0.043 \\
(0.054)\end{array}$ & $\begin{array}{c}0.152 * * * \\
(0.049)\end{array}$ \\
\hline Age & $\begin{array}{l}-0.211 \\
(0.185)\end{array}$ & $\begin{array}{c}0.364 * * * \\
(0.103)\end{array}$ & $\begin{array}{c}-0.019 \\
(0.089)\end{array}$ \\
\hline Education & $\begin{array}{c}0.213 \\
(0.245)\end{array}$ & $\begin{array}{c}0.397 * * * \\
(0.154)\end{array}$ & $\begin{array}{l}0.239^{*} \\
(0.141)\end{array}$ \\
\hline Income & $\begin{array}{l}-0.165 \\
(0.154)\end{array}$ & $\begin{array}{c}0.120 \\
(0.102)\end{array}$ & $\begin{array}{c}-0.144 * \\
(0.086)\end{array}$ \\
\hline Gender & $\begin{array}{c}0.368 \\
(0.274)\end{array}$ & $\begin{array}{l}-0.200 \\
(0.154)\end{array}$ & $\begin{array}{c}0.127 \\
(0.137)\end{array}$ \\
\hline Constant & $\begin{array}{c}0.944 \\
(1.194)\end{array}$ & $\begin{array}{c}0.832 \\
(0.789)\end{array}$ & $\begin{array}{l}1.252 * \\
(0.654)\end{array}$ \\
\hline Observations & 522 & 483 & 465 \\
\hline
\end{tabular}

Notes: This table reports estimates of Equations (1-3), additionally controlling for the survey item measuring distrust in financial markets. Interval regressions are used for Share_SI and Amount_OCDS as dependent variables. A Logit regression is used with the dependent variable OCDS invested, which takes the value 1 if a person is invested in OCDS, and 0 else. Independent variables include the three motivational variables, non-financials, financials, signaling, and four control variables, age, education, income and gender. Furthermore, we include here the absolute return and risk expectations of SI and OCDS, and the relative return and risk expectations of SI and OCDS in relation to stocks (relative return / risk SI and OCDS). 
Table 12 Types of ESG Investments and Categorization into Non-listed SI / Impact and Listed SI

\begin{tabular}{l|l} 
Other microfinance investments & Non-listed SI / Impact \\
\hline Other assets in developing countries & Non-listed SI / Impact \\
\hline $\begin{array}{l}\text { Companies or funds in environment protection, alterna- } \\
\text { tive energy }\end{array}$ & Non-listed SI / Impact \\
\hline Social companies in Switzerland / Europe & Non-listed SI / Impact \\
\hline $\begin{array}{l}\text { Bonds (sovereign, company) / obligation funds with sus- } \\
\text { tainable profile (e.g. „Green Bonds“) }\end{array}$ & Listed SI \\
\hline Equity / options / funds with ESG profile & Listed SI \\
\hline & Non-listed SI / Impact \\
Direct participation in companies with sustainable profile & \\
\hline Charitable endowment with foundation & Non-listed SI / Impact \\
\hline No other & Not considered
\end{tabular}

Notes: This table reports reclassification of categorical response items to types of SI investments into publicly listed SI in general versus non-listed SI / impact investments in particular. Answer frequencies are then used to classify respondents as either "general SI investors" or "impact investors". "Impact investors" hold at least one impact investment and zero listed SI products.

Table 13 Impact Investors Versus Public ESG Investors : Importance of Factors and Relative Return Expectation

\begin{tabular}{|c|c|c|}
\hline VARIABLES & $\begin{array}{c}\text { (1) } \\
\begin{array}{c}\text { Share_SI for Impact In- } \\
\text { vestors }\end{array}\end{array}$ & $\begin{array}{c}(3) \\
\text { Share_SI for other SI Investors }\end{array}$ \\
\hline NonFinancials & $\begin{array}{l}0.515^{*} \\
(0.273)\end{array}$ & $\begin{array}{l}-0.027 \\
(0.117)\end{array}$ \\
\hline Financials & $\begin{array}{l}-0.286 \\
(0.202)\end{array}$ & $\begin{array}{c}0.310 * * * \\
(0.119)\end{array}$ \\
\hline Signalling & $\begin{array}{l}-0.186 \\
(0.192)\end{array}$ & $\begin{array}{c}-0.275^{*} \\
(0.151)\end{array}$ \\
\hline Relative Return OCDS & $\begin{array}{c}0.034 \\
(0.279)\end{array}$ & $\begin{array}{c}0.012 \\
(0.173)\end{array}$ \\
\hline Relative Return SI & $\begin{array}{c}0.074 \\
(0.281)\end{array}$ & $\begin{array}{c}0.112 \\
(0.174)\end{array}$ \\
\hline Age & $\begin{array}{l}-0.051 \\
(0.260)\end{array}$ & $\begin{array}{c}-0.005 \\
(0.147)\end{array}$ \\
\hline Education & $\begin{array}{c}0.463 \\
(0.394)\end{array}$ & $\begin{array}{c}0.467 * * \\
(0.229)\end{array}$ \\
\hline Income & $\begin{array}{c}-0.744 * * * \\
(0.248)\end{array}$ & $\begin{array}{l}-0.120 \\
(0.132)\end{array}$ \\
\hline Gender & $\begin{array}{c}0.502 \\
(0.377)\end{array}$ & $\begin{array}{c}-0.064 \\
(0.240)\end{array}$ \\
\hline Constant & $\begin{array}{c}2.521 \\
(1.983)\end{array}$ & $\begin{array}{c}1.746 \\
(1.086)\end{array}$ \\
\hline Observations & 62 & 164 \\
\hline
\end{tabular}

Notes: This table reports estimates of Equations (1-3), differentiating the sample according to Table 12 into impact investors and investors in listed SI (stocks / bonds). An Interval regression is used for share_SI. Independent variables include the factor variables, non-financials, financials, signaling, and four control variables, age, education, income and gender. Furthermore, we include here the relative return and risk expectation of SI / OCDS in relation to stocks (relative return / risk SI / OCDS). 
Table 14 Investment Decisions Based on Motivational Aspects and Relative Risk and Return Expecations : (Ordered) logit Regressions

\begin{tabular}{lccc}
\hline \multirow{3}{*}{ VARIABLES } & $(1)$ & $(2)$ & $(3)$ \\
NonFinancials & OCDSinvested & v18_actualocdsinv & v17_shareesg \\
\hline \multirow{3}{*}{ Financials } & $0.332^{* * *}$ & 0.035 & $0.233^{* *}$ \\
& $(0.103)$ & $(0.094)$ & $(0.116)$ \\
Signalling & $-0.234 *$ & $0.261 * * *$ & 0.115 \\
& $(0.132)$ & $(0.085)$ & $(0.092)$ \\
Age & 0.125 & $-0.192^{* *}$ & $-0.206^{* *}$ \\
& $(0.140)$ & $(0.096)$ & $(0.100)$ \\
Education & -0.223 & $0.377^{* * *}$ & -0.002 \\
& $(0.184)$ & $(0.114)$ & $(0.118)$ \\
Income & 0.264 & $0.478^{* * *}$ & $0.342^{*}$ \\
& $(0.242)$ & $(0.172)$ & $(0.204)$ \\
Gender & -0.198 & 0.130 & $-0.207 *$ \\
& $(0.151)$ & $(0.115)$ & $(0.120)$ \\
Constant & 0.327 & -0.227 & 0.139 \\
& $(0.269)$ & $(0.174)$ & $(0.185)$ \\
Observations & 1.354 & & \\
& $(1.135)$ & & \\
& 526 & 486 & \\
\hline
\end{tabular}

Notes: This table reports estimates of Equations (1-3). Ologit regressions are used for amount_OCDS and share_SI as dependent variables. Independent variables include three motivational variables, non-financials, financials, signaling, and four control variables, age education, income and gender. 